\title{
THE ANATOMY OF FACELINELLA QUADRILINEATA (BABA) (NUDIBRANCHIA-EOLIDOIDEA)
}

\author{
$\operatorname{AUTHOR}(\mathrm{S})$ : \\ Baba, Kikutaro
}

\section{CITATION:}

Baba, Kikutaro. THE ANATOMY OF FACELINELLA QUADRILINEATA (BABA)

(NUDIBRANCHIA-EOLIDOIDEA). PUBLICATIONS OF THE SETO MARINE BIOLOGICAL LABORATORY 1965, 12(5): 409-414

ISSUE DATE:

1965-03-10

URL:

http://hdl.handle.net/2433/175377

RIGHT: 


\title{
THE ANATOMY OF FACELINELLA QUADRILINEATA (BABA) (NUDIBRANCHIA-EOLIDOIDEA)
}

\author{
KiKuTARÔ BABA \\ Biological Laboratory, Osaka Gakugei University, Osaka
}

With Plates XXVI-XXVII

It has been suggested by Lemche (1964 c) to authorize Facelina Alder \& HanCOCK, 1855 as the type of the Facelinidae (here used in the family rank), and Eolida coronata Forbes \& Goodsir, 1839 as the type of the genus. According to him, E. coronata is specifically identical with Doris auriculata (cf. ODHNER, 1939, p. 80), and so the first of the species of Facelina to be listed becomes entitled thus : F. auriculata (O. F. MülLER, 1776). On the animal of this species, the body is very large (about $25 \mathrm{~mm}$ long), the rhinophores are distinctly laminated, the branchial papillae are placed in clusters, the radula teeth are narrowly horseshoe-shaped, and the penis, discoid or tongue-shaped, is provided with marginal papillae or spines (cf. A. \& H., 1846 and 1855 ; Eliot, 1910, p. 171 ; Odhner, 1939, p. 78 , text-figs. 44, 46). And these articles may be presumed as making up the primary definition of the Atlantic genus Facelina.

As the genus grows more extensive with the addition of new members from various seas of the world (cf. MArcus, 1958, pp. 56-57), the scope of it seems to have become more or less obliterated. Furthermore, the family itself does not appear to be satisfactorily defined (see also the discussion by RissoDominguez, 1962). According to Risso-Dominguez, 1962, Acanthopsole Trinchese, 1874 (type: Aeolis rubrovittata Costa, 1866, Mediterranean ; cf. Pruvot-Fol, 1954, p. 392, text-fig. 151, g-k) is a genus to be separated from the typical Facelina. The present author is now forced to prepare comments on Facelinella BABA, 1949 in order to compare it with Facelina (and the allies) more precisely than before.

Willing cooperation has been offered by Messrs. Iwao Hamatani (Osaka Gakugei University) and Takeo AвE (Takaoka High School, Toyama Pref.) in collecting part of the specimens employed in this study.

Publ. Seto Mar. Biol. Lab., XII (5), 1965. (Article 30) 


\section{Facelinella quadrilineata (BABA, 1930)}

Hervia quadrilineata BABA, 1930, pp. 119-121, 124, pl. 4, fig. 3, text-figs. 2a-2c.-Tateyama Bay. Cuthona (Hervia) quadrilineata, var. BABA, 1935, pp. 356-357, pl. 6, fig. 3, text-fig. 17-Mutsu Bay.

Cuthona (Hervia) quadrilineata BABA, 1937, p. 329 (listed only).

Facelinella quadrilineata BABA, 1949, pp. 108-109, 181-182, pl. 48, figs. 162-163, text-figs. 147-148. -Sagami Bay; ABE, 1964, pp. 71-72, pl. 34, fig. 122.-Toyama Bay and vicinity.

In Japanese waters this species is widely spread on the Pacific coasts (Mutsu Bay; Onagawa Bay; Tateyama Bay ; Sagami Bay; Shima ; Osaka Bay) as well as on the Japan Sea side (Sado Is.; Toyama Bay; Hekurajima I.; W. coast of Noto Peninsula; Tsuruga Bay). It is fairly common, and specimens were collected usually from underneath pebbles in the intertidal zone. The natural diet of this species could not be made out

Observation was made preferably on live animals, the actual specimens being obtained by the author or by his friends from various stations. For the examination of the internal organs, three of the specimens listed below were prepared in serial sections stained by Delafield's haematoxylin and eosin.

Sp. No. 1. Loc.: Sugashima, Shima. Date: Apr. 8, 1951. (H. S.)

Sp. No. 2. Loc.: Tsuruga Bay. Date: Aug. 1, 1961. (H. S.)

Sp. No. 3. Loc.: Tsuruga Bay. Date: Aug. 1, 1961. (T. S.)

Each of the sectioned specimens was in a matured state.

Externals: The general body-form and colours have repeatedly been reported before (BABA, 1930, 1935 and 1949; ABE, 1964). The length (Code Ac) is usually between 10 and $20 \mathrm{~mm}$, and the maximum length measured was $23 \mathrm{~mm}$. The body proper is narrowed. The cephalic tentacles are exceedingly slender. The rhinophores are shorter, and smooth in the fully extended condition; when contracted, they are apt to show slight constrictions (or perfoliations, or rings, according to different views) on their entire length. But unlike in Facelina auriculata, they can hardly be said as forming distinct perfoliations or laminated leaves on the upper half. The foot-corners are tentaculiform. The tail is rather short, and tapering behind. On examination of the sectioned material, it was found that the liver system in Facelinella is constructed almost as in the case of Facelina: the branchial rows belonging to the left posterior liver are collected into a series of clusters on each back-margin. The right liver (and the left-sided partner) consists of 6-9 rows. The papillae themselves are elongated fusiform in full extension, deciduous, and number at most 8 on the largest rows. For the anus, nephroproct and genital orifice reference is to be made to the annexed figures. Of the details of colouring, there may be seen a slight variation according to different specimens. Typically (BABA, 1930 and 1949) the animal has two pairs of chocolate brown lines on the head between cephalic tentacles and rhinophores, besides two parallel-running ones 
on each side of the body. On some specimens, however, these lines decreased in number, or they came to fade away altogether from sides (BABA, 1935). The lower half of each of the cephalic structures is chocolate brown. The anterior margin of the foot is bordered with the same colour. A cluster of opaque white dots may be present on the top of these cephalic structures, in the median line of the head or of the tail, on the pericardial prominence, on the branchial papillae below the tip, and more thickly on the body-sides. Usually the branchial papillae are capped with orange-yellow or yellow, their veins (= liver-diverticula) being melanin black. The ground-colour of body including the sole is of a translucent yellowish white.

Internals: The main diagnoses of the jaw-plates and radula have also been noted repeatedly (BABA, 1930, 1935 and 1949). The central tooth is typically horsehoe-shaped and narrowed as in Facelina auriculata. A liver system of Facelina-type was secured in Facelinella. Almost the whole inner surface of the digestive tract excepting the liver-diverticula is covered with short cilia. The salivary glands appear to be branching. In a contracted state the liver-diverticulum within each of the papillae assumes a corrugated appearance on the surface. As one of the distinctions in colours of this species, the entire length of the diverticulum is thickly laden with melanin pigment granules towards its outer wall. On superficial observation, the fresh diverticular epithelium is mixed with yellow cells and colourless ones. The cnidocysts of the cnidophore sac are filled with nematocysts, leaving no room for the formation of colourless droplets. The reno-pericardial canal has a plicate wall. The main canal of the kidney sends off dendriform branches on either side. The penis in this species, though armed, cannot exactly be identified with the ejaculatory penis in Facelina auriculata. It consists of two parts: The distal part is a short cylindrical formation which is thickly interlaced with muscle fibres (circular and longitudinal), and covered with strong cilia on the surface. The proximal portion makes up a highly extensible cushion. In texture the cushion is rather loosely muscular, and lacunose. The whole length of the penis includes a rich supply of basophile gland cells. On the upper side of the penis there is a longitudinal row of minute chitinous spines, and this row is repeated completely on the opposite side of the same organ. The prostatic vas deferens opens into the lumen of the penis sheath, after passing icross the ground of the cushion. The male and female orifices are united. The general composition of the accessory genital complex is approximately as in Facelina auriculata. It is also like in Rizzolia lineata and Favorinus japonicus. Each of the gonadial follicles generates both sperms and eggs.

Remarks: Facelinella agrees completely with Facelina in the branchial papillae set in clusters, and in the liver system. But it was revealed that the penis in Facelinella, though armed with serial spines, is devoid of a vas deferens passing through, and so differs materially from the ejaculatory penis of 
Facelina. As for Facelinella anulifera BABA, 1949, re-examination by a sectioning method was made on the specimens in the author's collection. The results gained were that there occur serial marginal spines on the non-ejaculatory penial hood, and that the penis itself is more or less peculiar in shape. The matters are expected to be shown more adequately in a separate paper.

\section{REFERENCES}

(Continued to the previous papers of the author appeared in the Publications of the Seto Marine Biological Laboratory, vols. IX-XII).

ALDER, J. \& HANCOCK, A. 1846, 1855. A monograph of the British nudibranchiate Mollusca. Pt. 2 (fam. 3, pl. 12, Eolis coronata); Pt. 7, Pl. 47, suppl. (fig. 7, Eolis coronata, radula tooth) and Appendix (p. 22, Facelina).

BABA, K. 1930. Studies on Japanese nudibranchs. 3. Venus, vol. 2, no. 3.

1935. Report of the biological survey of Mutsu Bay. 27. Nudibranchia of Mutsu Bay. Sci. Rep. Tôhoku Imp. Univ., ser. 4, Biol., vol. 10, no. 2.

_... 1937. Opisthobranchia of Japan. 2. Journ. Dept. Agric. Kyâshû Imp. Univ., vol. 5, no. 7 .

1949. Opisthobranchia of Sagami Bay. Iwanami Shoten, Tokyo.

ElIOT, C. 1910. A monograph of the British nudibranchiate Mollusca. Pt. 8 (Suppl.).

LEMCHE, H. 1964c. Facelina ALDER \& HANCOCK, 1855 (Gastropoda): proposed addition to the Official List. Z.N. (S.) 1104. Bull. zool. Nomencl., vol. 21, pt. 1.

Trinchese, S. 1874. Intorno ai generi Hermaeina e Acanthopsole. Mem. Accad. Sci. Ist. Bologna, ser. 3 , tom. 5 , fasc. 1 (not directly referred to).

\section{EXPLANATION OF PLATES XXVI-XXVII}

\section{Plate XXVI}

Figs. 1-7.

Facelinella quadrilineata.

Fig. 1.

Fig. 2.

Entire animal in life, right side view, length (Code Ac) $20 \mathrm{~mm}$. Material: Hayamz, Sagami Bay (Apr. 26, 1951). Showing typical colouration.

Fig. 3.

The same animal as above. Showing chocolate brown lines on the head.

Entire animal in life, dorsal view, length (Code Ac) $20 \mathrm{~mm}$. Material : Sugashima, Shima (Apr. 9, 1951). Showing one of the colour variations with reduced lines on the head and sides.

Fig. 4. The same animal as above, right side view. The dotted parts on the side, pericardium and tail show clusters of opaque white dots.

Fig. 5.

Right side view of a naked animal, diagrammatic. Material : Sugashima, Shima (Apr. 8, 1951). a. anus, b. nephroproct, c. genital orifice. 
Figs. 6 a-6 b. Paired jaw-plates, outside view. Material: Tomogashima, Osaka Bay (Aug. 19, 1963). Jaws slightly yellowish brown; about 30 denticles on each jaw-edge. $6 \mathrm{a} . \times 40 ; 6 \mathrm{~b} . \times 70$.

Fig. 7. A central tooth $(\times 130)$ taken from the proximal (new) end of the radula ribbon (formula $20 \times 0.1 .0$ ). Material: as above. Denticles $4-5$ on each side. Teeth colourless in fresh.

Figs. 8-10. Facelinella anulifera.

Fig. 8. Entire animal in life, dorsal view, length (Code Ac) $13 \mathrm{~mm}$. Material: Sugashima, Shima (May 7, 1951). Rhinophores with 7-8 rings. Ground-colour yellowish white. Back and sides spotted all over with opaque white. A pair of vermilion lines on head and behind rhinophores. A series of vermilion arcs on each back-margin, each arc lying between branchial clusters. A longitudinal vermilion line on each side of body, between cephalic tentacle and tail. Cephalic tentacles with two yellow rings at about the mid-length, the upper half opaque white. Rhinophores pale orange-yellow below, opaque white above. Branchial papillae with several longitudinal rows of opaque white dots down the tip, their veins (= liver-diverticula) dark brown and thickly loaded with melanin pigment granules. Tail above opaque white in the median line.

Fig. 9. Part of the denticulations on the jaw-edge $(\times 130)$. Material: Sugashima, Shima (Apr. 7, 1951). Denticles 25 in all.

Figs. 10 a -10 b. Radula teeth (formula of the entire radula ribbon $22 \times 0.1 .0$ ). Material : as above. Denticles 5 on each side. 10 a. A central tooth from the proximal end of the ribbon, dorsal view $(\times 95)$; $10 \mathrm{~b}$. Two central teeth from the distal (old) end of the ribbon, lateral view $(\times 95)$.

\section{Plate XXVII}

Figs. 1-9. Facelinella quadrilineata.

Fig. 1.

Digestive system in the body, diagrammatic. Main material:

Sp. No. 1. a. right liver, b. genital orifice, c. reno-pericardial canal, d. nephroproct, e. anus, f. left posterior liver, g. kidney, h. left anterior liver.

Fig. 2. Entire aspect of the kidney. Material: Sp. No. 1. a. renopericardial canal, b. nephroproct.

Fig. 3. Protruding penis figured from a horizontal section of the body $(\times 20)$. Material : Sp. No. 1. a. prostatic vas deferens, b. penis sheath, c. penis, d. cluster of basophile gland cells within the tissue of the penis, e. an upper longitudinal row of chitinous 
spines (another row is present on the under side of the penis), f. outer oviduct, g. opening of the prostatic vas deferens into the lumen of the penis sheath (this opening is situated just ventral to the ground of the penis, and may most clearly be demonstrated by serial transverse sections). This penis does not form an ejaculatory organ.

Fig. 4. Anatomy of the stomachal region. Material: Sugashima, Shima (May 5, 1951). a. stomach, b. right liver, c. intestine, d. left posterior liver, e. left anterior liver.

Figs. $5 \mathrm{a}-5 \mathrm{~b}$. Penis and its armatures in fresh. Material: Tomogashima, Osaka Bay (Aug. 19, 1963). 5 a. Part of the penis pressed down; 5 b. a row of colourless chitinous spines $(\times 70)$.

Fig. 6. Genital system in the body, diagrammatic. Main material: Sp. No. 2. a. salivary gland, b. genital orifice.

Fig. 7. A branchial papilla $(\times 40)$. Material: Sp. No. 2. Showing melanin pigment granules deposited in the diverticular epithelium.

Fig. 8. Genital organs from above, diagrammatic $(\times 30)$. Main material: Sp. No. 2. a. contracted penis, b. penis sheath, c. genital orifice, d. outer oviduct, e. area of gland B (? = mucous gland), f. area of gland $A(?=$ albumen gland), g. ampulla, h. spermatheca, i. area of gland $C(?=$ membrane gland $), j$. inner oviduct $(?=$ fertilization chamber), k. prostatic vas deferens. The composition of the accessory genital complex is nearly as in Rizzolia lineata.

Fig. 9. Transverse section of the body on level of the anus $(\times 30)$. a. lateral branches from the main canal (d) of the left posterior liver, b. main canal of kidney, c. hermaphrodite duct, e. anus, f. rectum. 
Publ. Seto Mar. Biol. Lab., XII, 5 (1965)

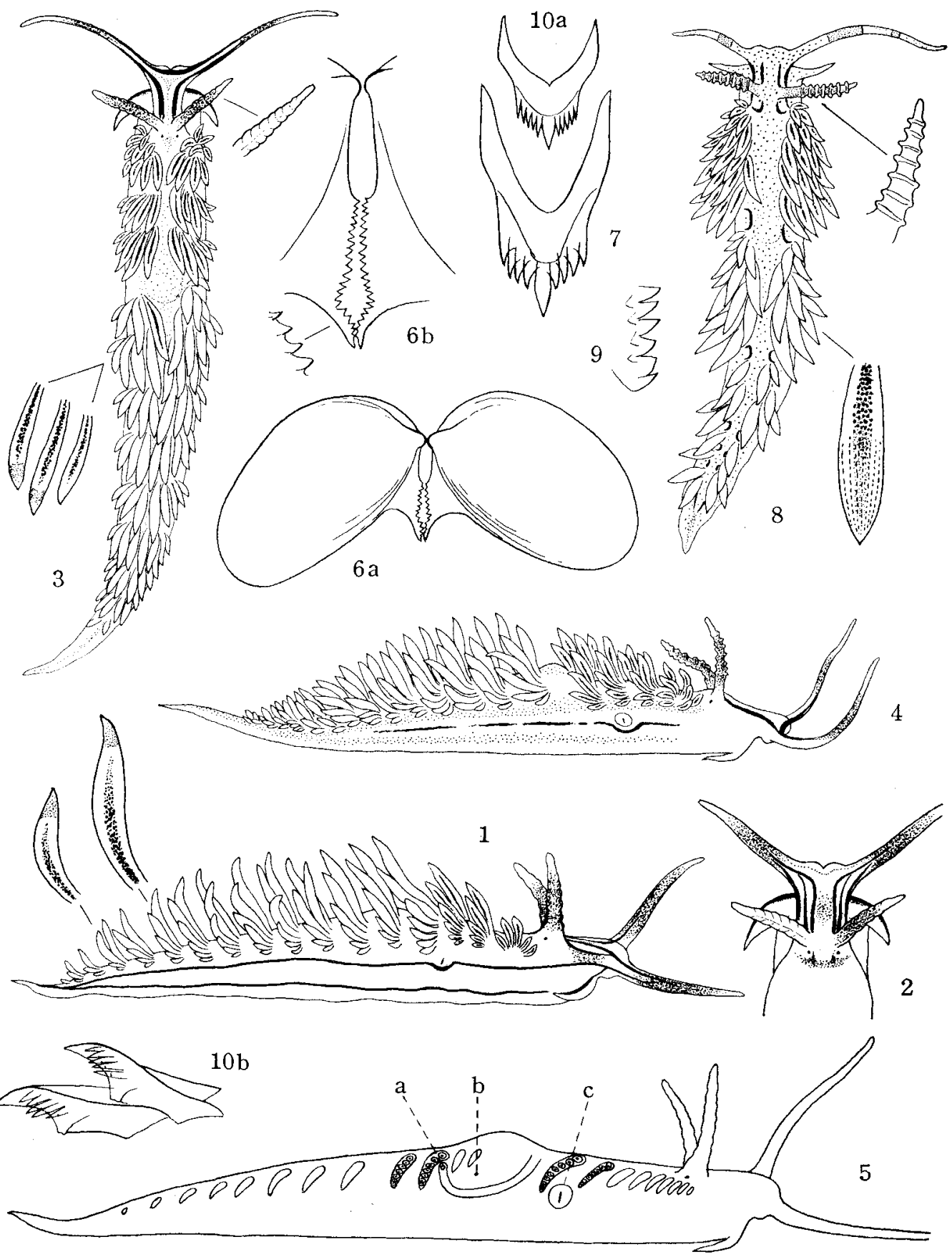

K. Baba: Anatomy of Facelinella quadrilineata (BABA). 
Publ. Seto Mar. Biol. Lab., XII, 5 (1965)

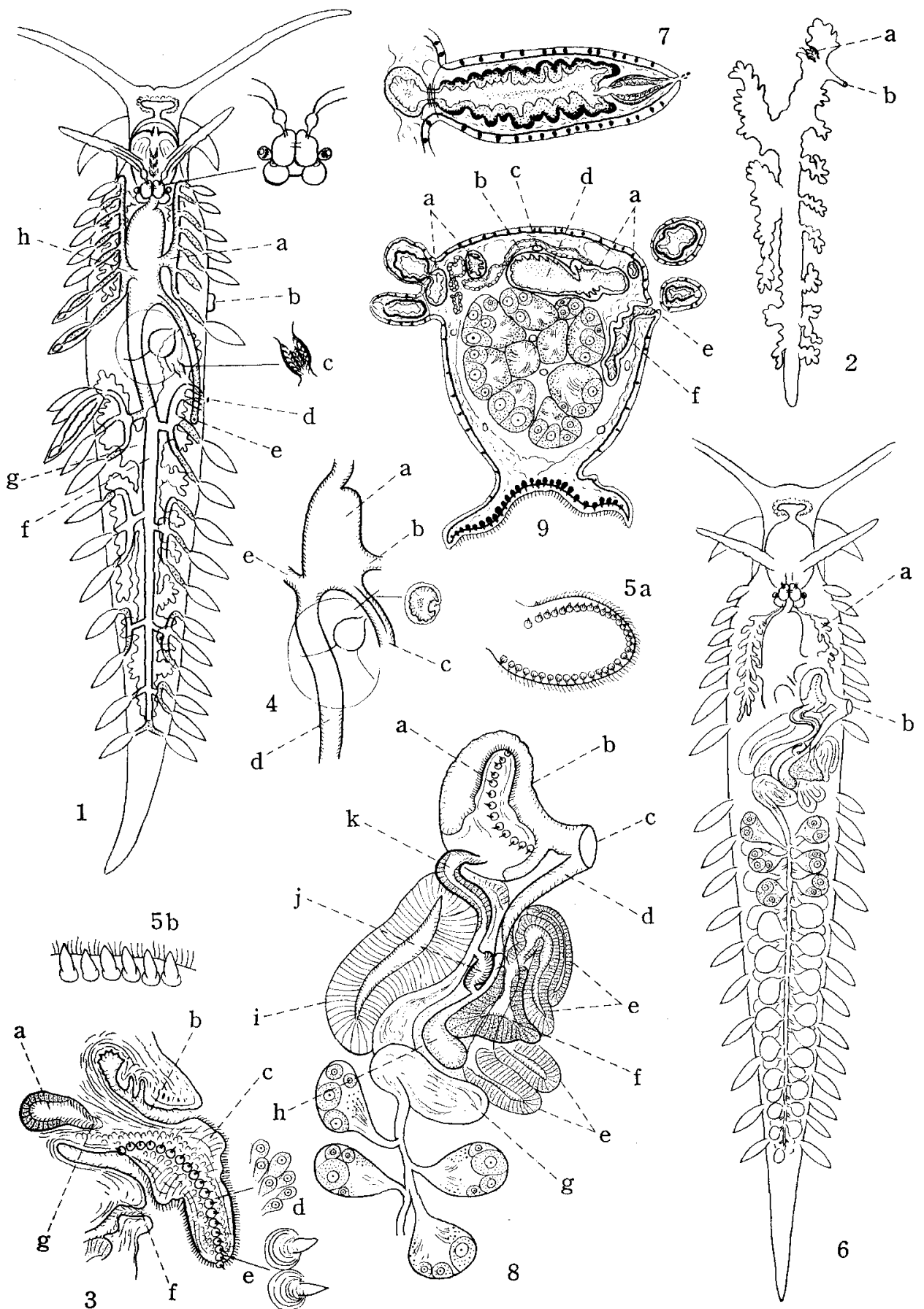

K. Baba: ANatomy of Facelinella quadrilineata (BABA). 